\title{
Characterization of glycerol kinase from baker's yeast: Response surface modeling of the enzymatic reaction
}

\author{
Caio Casale Aragon ${ }^{a}$, Suzana Ferreira-Dias ${ }^{\mathrm{b}}$, Edwil Aparecida de Lucca Gattás ${ }^{\mathrm{a}}$, \\ Maristela de Freitas Sanches Peres ${ }^{\text {a,* }}$ \\ ${ }^{a}$ School of Pharmaceutical Science, São Paulo State University, UNESP, Department of Food and Nutrition, \\ Rodovia Araraquara-Jaú, Km 1, 14801-902 São Paulo, Brazil \\ ${ }^{\mathrm{b}}$ Instituto Superior de Agronomia, DAIAT, Centro de Estudos de Engenharia Rural, Technical University of Lisbon, \\ Tapada da Ajuda, 1349-017 Lisbon, Portugal
}

Available online 17 November 2007

\begin{abstract}
The present study describes a methodology of dosage of glycerol kinase (GK) from baker's yeast. The standardization of the activity of the glycerol kinase from baker's yeast was accomplished using the diluted enzymatic preparation containing glycerol phosphate oxidase (GPO) and glycerol kinase. The mixture was incubated at $60^{\circ} \mathrm{C}$ by $15 \mathrm{~min}$ and the reaction was stopped by the SDS solution addition. A first set of experiments was carried out in order to investigate the individual effect of temperature $(T), \mathrm{pH}$ and substrate concentration $(S)$, on GK activity and stability. The $\mathrm{pH}$ and temperature stability tests showed that the enzyme presented a high stability to $\mathrm{pH} 6.0-8.0$ and the thermal stability were completely maintained up to $50{ }^{\circ} \mathrm{C}$ during $1 \mathrm{~h}$. The $K_{\mathrm{m}}$ of the enzyme for glycerol was calculated to be $2 \mathrm{mM}$ and $V_{\max }$ to be $1.15 \mathrm{U} / \mathrm{mL}$. In addition, modeling and optimization of reaction conditions was attempted by response surface methodology (RSM). Higher activity values will be attained at temperatures between 52 and $56^{\circ} \mathrm{C}, \mathrm{pH}$ around $10.2-10.5$ and substrate concentrations from 150 to $170 \mathrm{mM}$.

This low cost method for glycerol kinase dosage in a sequence of reactions is of great importance for many industries, like food, sugar and alcohol. RSM showed to be an adequate approach for modeling the reaction and optimization of reaction conditions to maximize glycerol kinase activity.
\end{abstract}

(C) 2007 Elsevier B.V. All rights reserved.

Keywords: Glycerol kinase; Baker's yeast; Partial purification; Response surface methodology; Stability

\section{Introduction}

Glycerol kinase (GK, EC 2.7.1.30; ATP: glycerol 3phosphotransferase) catalyzes the transfer of the terminal phosphate of ATP to glycerol, to form $s n$-glycerol-3-phosphate and ADP. This enzyme plays a physiologically important role for the formation for glycerol-3-phosphate in the biosynthesis of phospholipids. In addition, the enzyme is industrially important and useful for the clinical determination of the blood triglyceride level in combination with lipase, glycerol-3-phosphate oxidase and peroxidase (PO) [1]. Up to now, GKs have been purified from several microorganisms [2-7] and a vertebrate [8], and

Abbreviations: GK, glycerol kinase; GPO, glycerol phosphate oxidase; PO, peroxidase; RSM, response surface methodology; $R^{2}$, determination coefficient (quadratic correlation coefficient); $R_{\text {adj }}^{2}$, adjusted $R^{2}$.

* Corresponding author. Tel.: +55 163301 6929; fax: +55 1633016920

E-mail address: fmrsperez@uol.com.br (M.de Freitas Sanches Peres). subsequently characterized. The genes of GK from Escherichia coli [9], Bacillus subtilis [10], Saccharomyces cerevisiae [11], Thermus flavus [12], Flavobacterium meningosepticum [13] and humans [14] have been cloned into E. coli, and the primary structures of their enzymes were determined. Comparison of these sequences suggests that the amino acid sequence of GK is relatively well conserved among various GKs. For example, the identity in the amino acid sequence between $E$. coli GK and human is $51 \%$. Comparisons of kinetic constants for enzymes from four microorganisms (C. mycoderma, S. cerevisiae, $E$. coli, and B. stearothermophilus) also indicated little variation among them [15], the $K_{\mathrm{m}}$ found was $5 \mathrm{mM}$ for glycerol for the salt-tolerant yeast Debaryomyces hansenii [16]. This is probably because GK is a key enzyme in glycerol metabolism and therefore the enzyme cannot be structurally and functionally divergent during evolution.

Beyond the colorimetric assay [17], glycerol kinase activity has been determined by several methods, including photomet- 
ric [18], spectrophotometric [3,8,17,19-24], radioisotopic [21], radiochemical [25-29], and chemiluminescent [30].

In this study, a GK was semipurified from dry baker's yeast and characterized. In a first set of experiments, the effect of temperature $(T), \mathrm{pH}$ and substrate concentration $(S)$, on GK activity and stability was investigated, in order to determine the most adequate variation ranges for each variable for GK activity. Afterwards, response surface methodology (RSM) was used for modeling and optimization of reaction conditions for glycerol kinase, as a function of reaction temperature $\left(46-64{ }^{\circ} \mathrm{C}\right)$, substrate concentration (48-162 $\mathrm{mM}$ of glycerol) and $\mathrm{pH}$ of the reaction medium (8.6-10.4).

RSM consists on a set of mathematical and statistical methods developed for modeling phenomena and finding combinations of a number of experimental factors (variables) that will lead to optimum responses [31,32]. With RSM, several variables are tested simultaneously with a minimum number of trials, according to special experimental designs, which enables to find interactions between variables [31,32]. This is not an option with classical approaches. In addition, RSM has the advantage of being less expensive and time-consuming than the classical methods.

The RSM has been used on modeling and optimization of several bioprocesses such as fermentation and enzymatic reactions [33-42], as well as on adsorption processes [43,44].

\section{Experimental}

\subsection{Microorganism}

Dry baker's yeast from Mauri Brazil Ind. Com. e Imp. Ltda.

\subsection{Cell disruption and crude cell extract preparation for enzymatic assay}

\subsubsection{Glycerol kinase and glycerol phosphate oxidase (GPO) of the dry baker's yeast}

The cells (10 g, dry weight) of baker's yeast were suspended in $100 \mathrm{~mL}$ of $2 \mathrm{mmol} / \mathrm{L}$ sodium citrate buffer, at $\mathrm{pH} 6.2$ containing $2 \mathrm{mmol} / \mathrm{L}$ of $\beta$-mercaptoethanol, and $100 \mathrm{~g}$ of glass beads $(425-600 \mu \mathrm{m})$ was added to the cells suspension and the disruption was carried out for $7 \mathrm{~min}$ in a Bead Beater (Biospec Products Inc., USA), cooled by ice and operated under full speed. The cells debris was separated by centrifugation for $10 \mathrm{~min}$ at $8,130 \times g$.

Cell extract was treated with $1 \%$ of streptomycin sulfate, and the clarified supernatant was obtained by centrifugation at $16,260 \times g$ for $20 \mathrm{~min}$ [45]. The first ammonium sulfate precipitation, a result from treatment with streptomycin sulfate, was added to the supernatant (35\% saturation), and the precipitate obtained by centrifugation $(16,260 \times \mathrm{g} / 20 \mathrm{~min})$ after $30 \mathrm{~min}$ at $4{ }^{\circ} \mathrm{C}$ was discarded. In the supernatant fraction of the present enzyme was added ammonium sulfate in the range $60 \%$ of saturation, and after one night at $4{ }^{\circ} \mathrm{C}$ the suspension was centrifuged $(16,260 \times g / 20 \mathrm{~min})$. The precipitate was dissolved in $1 \mathrm{~mL} 10 \mathrm{mmol} / \mathrm{L}$ Tris/ $\mathrm{HCl}$ buffer at $\mathrm{pH} 7.2$, and the fraction of enzyme was dialyzed for $24 \mathrm{~h}$ at $4{ }^{\circ} \mathrm{C}$ against a solu- tion of $2 \mathrm{mmol} / \mathrm{L}$ sodium citrate at $\mathrm{pH} 5.5$ containing $2 \mathrm{mmol} / \mathrm{L}$ $\beta$-mercaptoethanol, and $10 \mathrm{mmol} / \mathrm{L} \mathrm{MnSO}_{4}$, and this fraction, after centrifugation $(11,292 \times g / 10 \mathrm{~min})$ was used as the source of GK and GPO.

\subsubsection{Horseradish peroxidase}

The crude cell extract was obtained by disruption of the $500 \mathrm{~g}$ of peeled horseradish in an electric liquidizer with $20 \mathrm{~mL}$ of $0.1 \mathrm{M}$ acetate buffer at $\mathrm{pH}$ 5.0. The homogenate was filtered in gauze and it was clarified by centrifugation $(1,807 \times g, 10 \mathrm{~min})$ in refrigerated centrifuge, and used as peroxidase source.

\subsection{Glycerol phosphate oxidase assay}

GPO activity was determined by the peroxidase chromogen method as described by Šůcková et al. [46] with modifications. The absorbance at $500 \mathrm{~nm}$ (molar absorption coefficient of $6.65 \times 10^{3} \mathrm{M}^{-1} \mathrm{~cm}^{-1}$ ) was measured using a mixture of $750 \mu \mathrm{L}$ of glycerol-phosphate $0.5 \mathrm{M}$ in $0.1 \mathrm{M}$ Tris/ $\mathrm{HCl}$ buffer $\mathrm{pH} 8.0$ containing $0.1 \%$ Triton $\mathrm{X}-100 ; 150 \mu \mathrm{L}$ of 4 -aminoantipyrine $0.1 \%, 300 \mu \mathrm{L}$ of phenol $0.1 \% ; 15 \mu \mathrm{L}(1.5 \mathrm{U})$ of horseradish peroxidase; $100 \mu \mathrm{L}$ water. The reaction was started by adding $15 \mu \mathrm{L}$ of the preparation of enzyme diluted 10 -fold, and stopped with $300 \mu \mathrm{L}$ of SDS $10 \%$, after incubation at $60^{\circ} \mathrm{C}$ for $120 \mathrm{~min}$. The assay measures the production of the oxidated derivatives (quinone-imine) of 4-aminoantipyrine. One unit (U) of enzyme was defined as the amount of the enzyme producing $1 \mu \mathrm{mol}$ of $\mathrm{H}_{2} \mathrm{O}_{2}$ per minute.

\subsection{Peroxidase assay}

PO activity was determined by a spectrophotometric method at $460 \mathrm{~nm}$ using a mixture of $0.2 \mathrm{~mL}$ of $o$-dianisidine $15 \mathrm{mM}$; $0.2 \mathrm{~mL}$ of hydrogen peroxide $30 \mathrm{mM} ; 5 \mu \mathrm{L}$ of horseradish extract and $2.595 \mathrm{~mL}$ of $0.1 \mathrm{M}$ citrate-phosphate buffer at $\mathrm{pH} 5.5$. The assay measures the production of the oxidated derivatives of $o$-dianisidine during the first $15-90 \mathrm{~s}$ of the reaction rate (molar absorption coefficient of $11.3 \times 10^{3} \mathrm{M}^{-1} \mathrm{~cm}^{-1}$ ). One unit (U) of enzyme was defined as the unit of absorbance generated per minute in the assay conditions.

\subsection{Glycerol kinase assay}

Extracts and fractions were assayed as described by Huang et al. [17]. The reaction mixture contained $70 \mu \mathrm{L}$ of $50 \mathrm{mM}$ ATP, $50 \mu \mathrm{L}$ of $0.2 \mathrm{M}$ magnesium sulfate, $500 \mu \mathrm{L}$ of $0.05 \mathrm{M}$ glycerol in $0.4 \mathrm{M}$ glycine/ $\mathrm{NaOH}$ buffer $\mathrm{pH} 10.0,160 \mu \mathrm{L}$ of the preparation of enzyme diluted 60-fold containing glycerol-3-phosphate oxidase, $150 \mu \mathrm{L}$ of 4 -aminoantipyrine $0.1 \%, 300 \mu \mathrm{L}$ of phenol $0.1 \%$. The reaction was started by adding $100 \mu \mathrm{L}$ (10 U) of horseradish peroxidase, and stopped with $300 \mu \mathrm{L}$ of SDS $10 \%$, after incubation at $60^{\circ} \mathrm{C}$ for $15 \mathrm{~min}$. The absorbance at $500 \mathrm{~nm}$ (molar absorption coefficient of $6.65 \times 10^{3} \mathrm{M}^{-1} \mathrm{~cm}^{-1}$ ) was measured. One unit (U) of enzyme was defined as the amount of the enzyme catalyzing the formation of $1 \mu \mathrm{mol}$ of glycerol-3-phosphate/min at $60^{\circ} \mathrm{C}$. 


\subsection{Kinetic parameters}

The kinetic parameters, $K_{\mathrm{m}}$ and $V_{\max }$, for glycerol were estimated from the Lineweaver-Burks plots.

\subsection{First set of experiments}

The following experiments were carried out in order to determine the experimental domain for modeling and optimization of $\mathrm{GK}$ reaction conditions by $\mathrm{RSM}$.

\subsubsection{Effect of pH on glycerol kinase activity and stability}

The effect of $\mathrm{pH}$ on glycerol kinase activity was determined by assaying the enzyme activity at $60{ }^{\circ} \mathrm{C}$ at various $\mathrm{pH}$ levels, between 7.0 and 11.0 (Tris/ $\mathrm{HCl}$ buffer, $\mathrm{pH}$ 7.0-9.0; glycine/ $\mathrm{NaOH}$ buffer, $\mathrm{pH}$ 9.5-11.0). The $\mathrm{pH}$ stability of the enzyme was determined by measuring the enzymatic activity under standard enzyme assay conditions after incubating the enzyme at $30^{\circ} \mathrm{C}$ during 25 days, the following $0.01 \mathrm{M}$ buffer systems of varying $\mathrm{pH}$ were used: for $\mathrm{pH}$ values of 5.0 and 6.0 (sodium citrate buffer), 7.0, 8.0 and 9.0 (Tris/ $\mathrm{HCl}$ buffer), and 10.0 (glycine/ $\mathrm{NaOH}$ buffer).

\subsubsection{Effect of temperature on glycerol kinase activity and thermal stability}

The optimum temperature of glycerol kinase activity was determined by assaying enzyme activity at $\mathrm{pH} 10.0$ in $0.4 \mathrm{M}$ of glycine/ $\mathrm{NaOH}$ buffer, at temperatures of $40,50,60,70$ and $80^{\circ} \mathrm{C}$. The thermal stability of the enzyme was determined by measuring the enzymatic activity under standard enzyme assay conditions after incubating the enzyme solu- tion for $1 \mathrm{~h}$, at various temperatures of $30,40,45,50,55$ and $60{ }^{\circ} \mathrm{C}$

\subsection{Protein assay}

Total protein was assayed according to the method of Lowry, modified by Layne [47], using bovine serum albumin as the standard protein. The levels of total protein were $2.53-3.30 \mathrm{mg} / \mathrm{mL}$ for horseradish extract, and around of $12.5-13.2 \mathrm{mg} / \mathrm{mL}$ for yeast extract.

\subsection{Response surface experiments}

\subsubsection{Experimental design}

The best conditions for the enzymatic reaction were established via RSM. In this study, the experiments were carried out following a full factorial design with the addition of centre points, as a function of reaction temperature, substrate concentration and $\mathrm{pH}$ of the reaction medium. This matrix was replicated one time. Thus, a total of 22 experiments were carried out (Table 1): 16 factorial points (coded levels as $(+1)$ and $(-1)$ ); and 6 centre points (coded as 0 ). Temperature varied from 46 to $64{ }^{\circ} \mathrm{C}$, substrate concentration (glycerol) varied from 48 to $162 \mathrm{mM}$ and $\mathrm{pH}$ from 8.6 to 10.4 . The establishment of these variation ranges was based on the previous results obtained in preliminary experiments. These ranges contain the apparent optimum value for each factor. Concerning glycerol concentration, the range chosen corresponds to the values suggested by the preliminary experiments where no substrate limitation was observed, i.e. where zero-order kinetics was attained.

Table 1

Coded and decoded experimental design followed

\begin{tabular}{|c|c|c|c|c|c|c|c|}
\hline \multirow[t]{2}{*}{ Experiment no. } & \multirow[t]{2}{*}{ Replicate } & \multicolumn{3}{|l|}{ Coded matrix } & \multicolumn{3}{|l|}{ Decoded matrix } \\
\hline & & Temperature & [Substrate] & $\mathrm{pH}$ & Temperature $\left({ }^{\circ} \mathrm{C}\right)$ & [Substrate] $(\mathrm{mM})$ & $\mathrm{pH}$ \\
\hline 1 & 1 & -1 & -1 & -1 & 46 & 48 & 8.6 \\
\hline 2 & 1 & 1 & -1 & -1 & 64 & 48 & 8.6 \\
\hline 3 & 1 & -1 & 1 & -1 & 46 & 162 & 8.6 \\
\hline 4 & 1 & 1 & 1 & -1 & 64 & 162 & 8.6 \\
\hline 5 & 1 & -1 & -1 & 1 & 46 & 48 & 10.4 \\
\hline 6 & 1 & 1 & -1 & 1 & 64 & 48 & 10.4 \\
\hline 7 & 1 & -1 & 1 & 1 & 46 & 162 & 10.4 \\
\hline 8 & 1 & 1 & 1 & 1 & 64 & 162 & 10.4 \\
\hline $9(\mathrm{C})$ & 1 & 0 & 0 & 0 & 55 & 105 & 9.5 \\
\hline $10(\mathrm{C})$ & 1 & 0 & 0 & 0 & 55 & 105 & 9.5 \\
\hline $11(\mathrm{C})$ & 1 & 0 & 0 & 0 & 55 & 105 & 9.5 \\
\hline 12 & 2 & -1 & -1 & -1 & 46 & 48 & 8.6 \\
\hline 13 & 2 & 1 & -1 & -1 & 64 & 48 & 8.6 \\
\hline 14 & 2 & -1 & 1 & -1 & 46 & 162 & 8.6 \\
\hline 15 & 2 & 1 & 1 & -1 & 64 & 162 & 8.6 \\
\hline 16 & 2 & -1 & -1 & 1 & 46 & 48 & 10.4 \\
\hline 17 & 2 & 1 & -1 & 1 & 64 & 48 & 10.4 \\
\hline 18 & 2 & -1 & 1 & 1 & 46 & 162 & 10.4 \\
\hline 19 & 2 & 1 & 1 & 1 & 64 & 162 & 10.4 \\
\hline $20(\mathrm{C})$ & 2 & 0 & 0 & 0 & 55 & 105 & 9.5 \\
\hline $21(\mathrm{C})$ & 2 & 0 & 0 & 0 & 55 & 105 & 9.5 \\
\hline $22(\mathrm{C})$ & 2 & 0 & 0 & 0 & 55 & 105 & 9.5 \\
\hline
\end{tabular}


The addition of six centre points $\left(55^{\circ} \mathrm{C}, 105 \mathrm{mM}\right.$ of substrate and $\mathrm{pH}$ 9.5) allows checking the curvature of the response surface fitted to the experimental points. With this experimental design, three levels for each factor were used which enables to fit second-order polynomials to the experimental data points. Therefore, curved surfaces can be fitted to the experimental data. Partial differentiation of these polynomial equations may be used to find the optimum points, i.e. the stationary points [31]. However, the identification, for each variable, of the regions corresponding to optimal responses, may be directly achieved by visual examination of the response surfaces and/or contour plots.

\subsubsection{Statistical analysis}

All the considered data presented standard deviation of up to $5 \%$. The results of the 22 experiments were analyzed using the software "Statistica ${ }^{\text {TM", }}$ Version 6, from Statsoft, Tulsa, USA. Both linear and quadratic effects of each of the independent variables (factors) under study, as well as their interactions, on glycerol kinase activity were calculated. Their significance was evaluated by analysis of variance. A surface, described by a firstor a second-order polynomial equation was fitted to the set of experimental data points. First- and second-order coefficients of these equations are usually unknown and, therefore, were estimated from the experimental data by using the statistical principle of least squares. The fit of the model was evaluated by the determination coefficients $\left(R^{2}\right)$ and adjusted $R^{2}\left(R_{\text {adj }}^{2}\right)$ $[31,48]$. In practice, $R^{2}$ should be at least 0.75 or greater; values above 0.90 are considered to be very good [48].

\section{Results and discussion}

\subsection{Optimization of the glycerol kinase assay}

The linear range of the assay was adjusted by shorting the reaction time and determining the dilution of enzyme

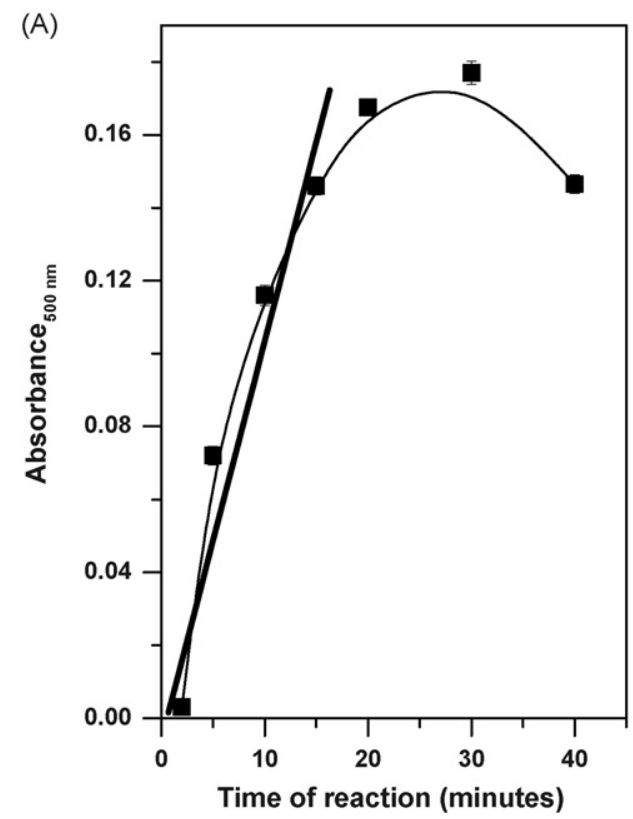

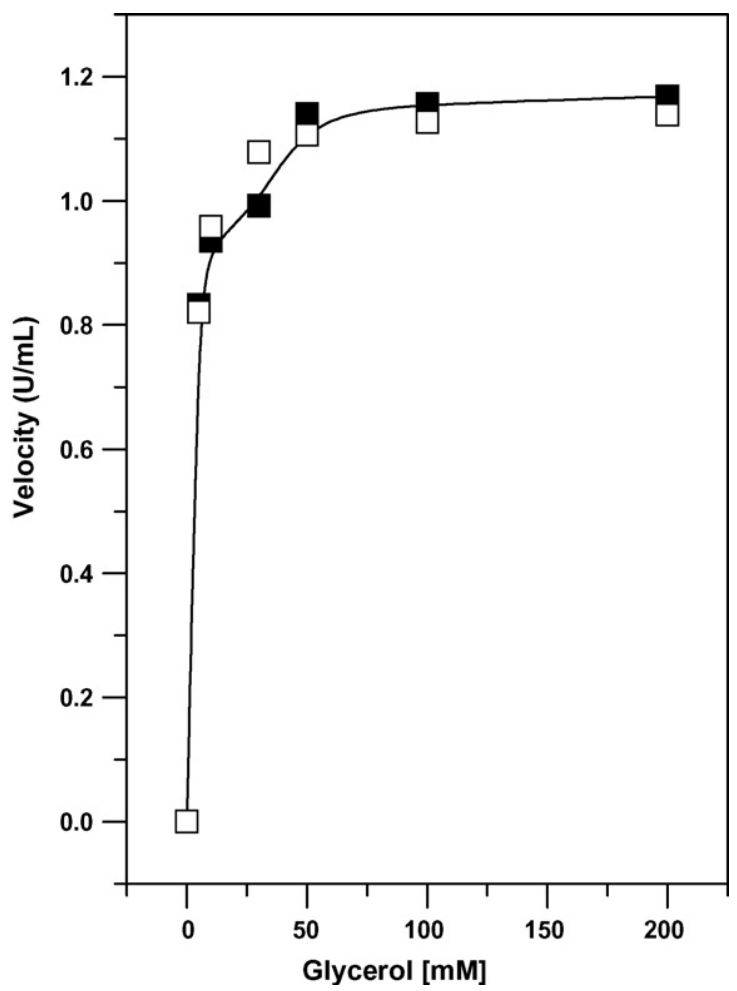

Fig. 2. GK activity obtained for different standard solution of glycerol. The data in closed squares represent the experimental data and in the open symbols are the theoretical values estimated by the equation of Michaëlis-Menten.

(Fig. 1). The glycerol kinase kinetics is well described by the Michaëlis-Menten model (Fig. 2). For glycerol concentrations higher than about $50 \mathrm{mM}$, a zero-order reaction is observed. A 15-min reaction time, a dilution of enzyme up to 60 times, and a concentration of peroxidase of $100 \mu \mathrm{L}$ and substrate of $50 \mathrm{mM}$, seems to be the best conditions for the determination of the GK activity.

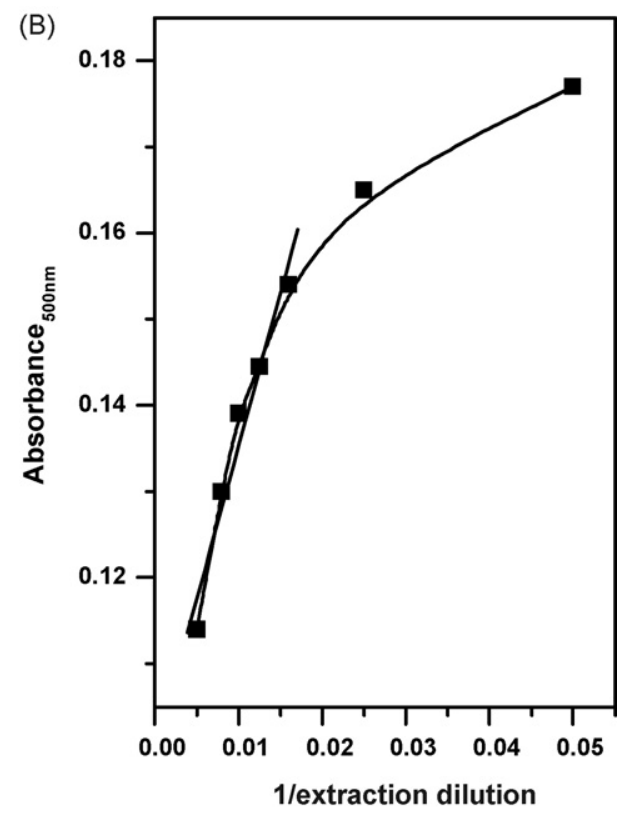

Fig. 1. Absorbance values obtained for standard solution of glycerol at different reaction time (A) and dilutions of the cellular extract (B). 

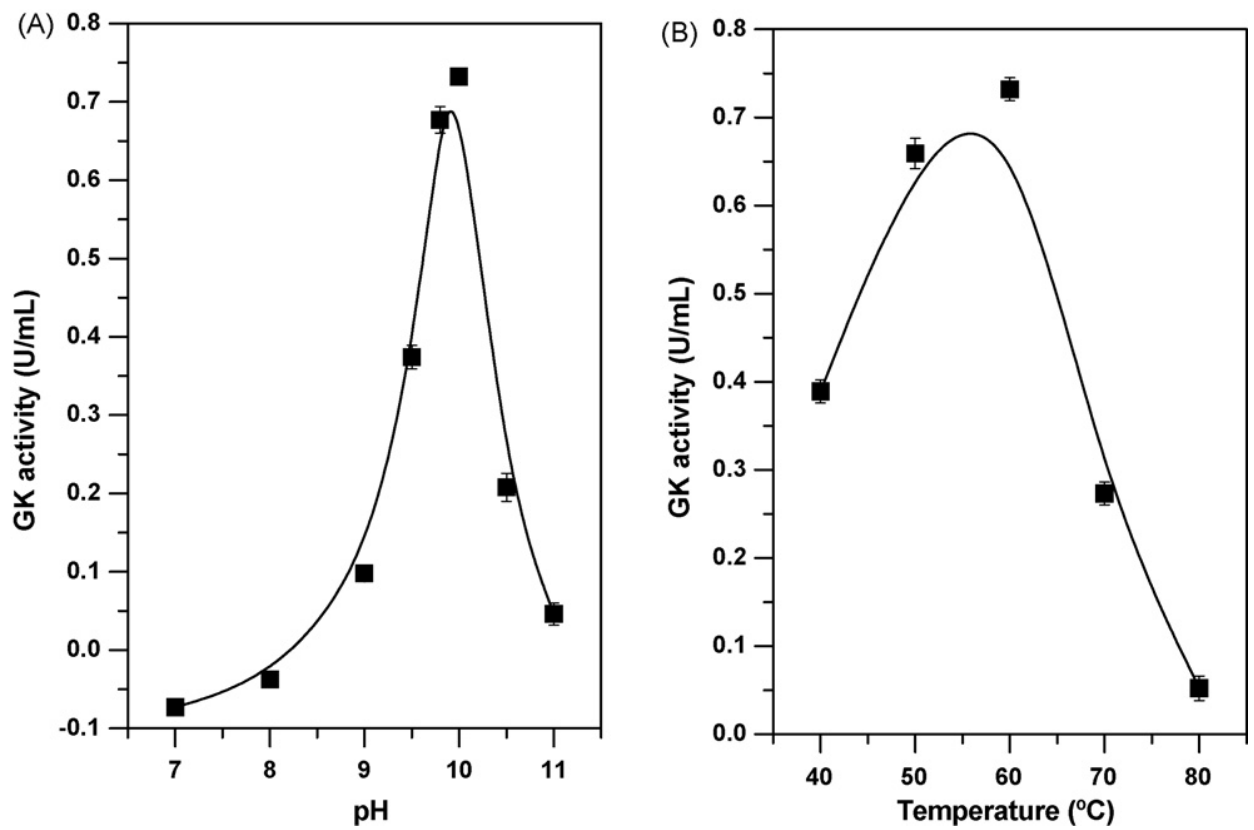

Fig. 3. Influence of $\mathrm{pH}(\mathrm{A})$ and temperature (B) on glycerol kinase activity. The $\mathrm{GK}$ was assayed in the $\mathrm{pH}$ range 7.0 and 11.0 , using various buffers (Tris- $\mathrm{HCl}$ buffer, $\mathrm{pH}$ 7.0-9.0; glycine/ $\mathrm{NaOH}$ buffer, $\mathrm{pH}$ 9.5-11.0). The optimum temperature of glycerol kinase activity was determined by assaying enzyme activity at $\mathrm{pH}$ 10.0 in $0.4 \mathrm{M}$ of glycine/ $\mathrm{NaOH}$ buffer, at temperatures of $40,50,60,70$ and $80^{\circ} \mathrm{C}$.

\subsection{Effect of $p H$ and temperature on glycerol kinase activity}

Crude cellular extracts from dry baker's yeast were obtained as described above, and the $\mathrm{pH}$ and temperature curves for the assay of the activity of the glycerol kinase can be observed in Fig. 3. The highest activity was found at $\mathrm{pH} 10.0$ and at a temperature of $60^{\circ} \mathrm{C}$. The optimum $\mathrm{pH}[17,49,50]$ and temperature $[17,50]$ for the assay system have been established by others. Our values of temperature and $\mathrm{pH}$ are similar to those reported in the literature for glycerol kinase of T. flavus [17] and for E. coli [3], respectively. However, these values may be only pseudo-optimum $\mathrm{pH}$ and temperature values, since the effect of interactions among factors was not considered. In the second set of experiments, the RSM will be used as an attempt to find out the real optimal conditions for GK activity.

\subsection{Stability of glycerol kinase activity at different $p H s$ and temperatures}

The thermal stability was obtained by measuring the activity, after incubation of the enzyme for $1 \mathrm{~h}$ at temperatures of 30,40 , $45,50,55$ and $60^{\circ} \mathrm{C}$, as shown in Fig. 4 ; in relation to the $\mathrm{pH}$ (5-10) stability, the activity was determined during 25 days at $30^{\circ} \mathrm{C}$, as shown in Fig. 5. The results obtained showed that the enzyme presented a wide range stability to $\mathrm{pH}(6.0-8.0)$, and the thermal stability was completely maintained up to $50^{\circ} \mathrm{C}$, after which its activity gradually decreased. This glycerol kinase in $S$. cerevisiae was stable in a wide range of $\mathrm{pH}$ and coincides with other microorganisms [13]. The enzyme was unexpectedly thermostable, and its thermostability is similar to that of GK from B. stearothermophilus, a moderate thermopile [13].

\subsection{Catalytic properties}

In the experiments by varying the concentrations of substrate, the kinetic data were obtained by double reciprocal plot of initial reaction rates and the concentration of glycerol. The $K_{\mathrm{m}}$

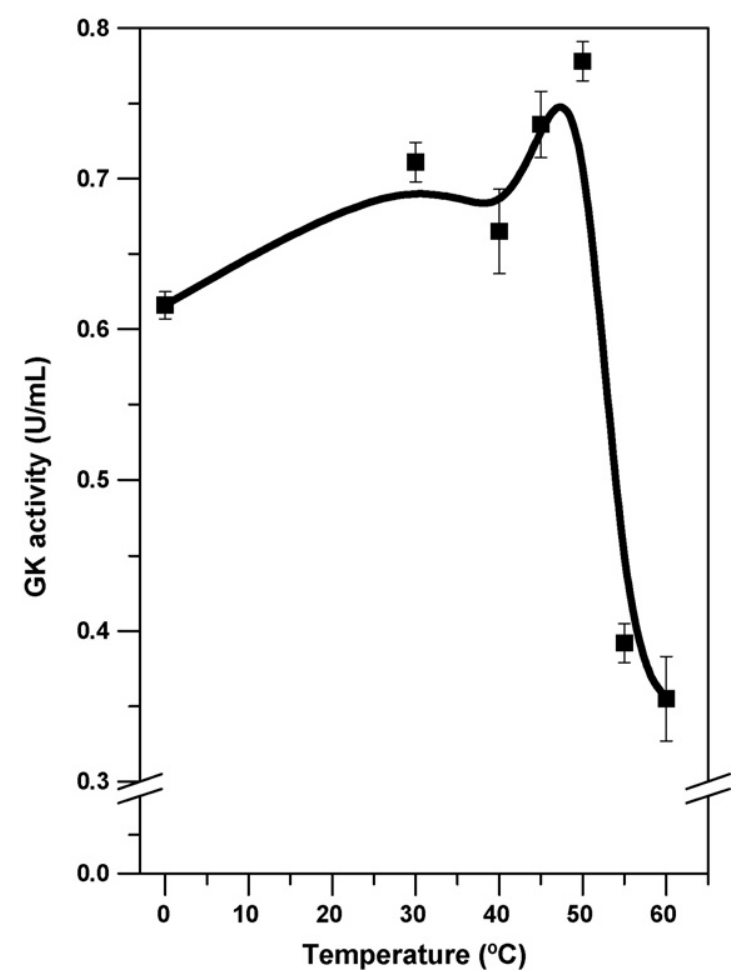

Fig. 4. Effect of temperature on GK stability. In the experiments, the enzyme solution was incubated for $1 \mathrm{~h}$, at various temperatures of $30,40,45,50,55$ and $60{ }^{\circ} \mathrm{C}$. 


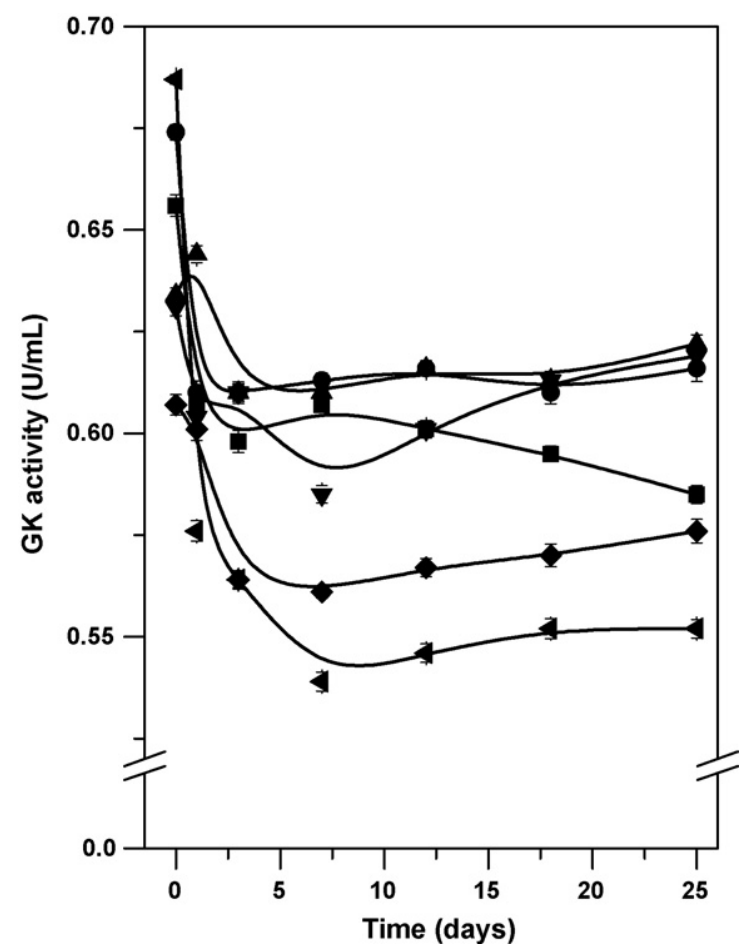

Fig. 5. Effect of $\mathrm{pH}$ on GK stability. In the experiments, the buffers used were as follows: $0.01 \mathrm{M}$ sodium citrate buffer $(\mathrm{pH} 5.0(\mathbf{\square})$ and $\mathrm{pH} 6.0(\bullet))$, Tris/ $\mathrm{HCl}$ buffer (pH $7.0(\mathbf{\Lambda}), \mathrm{pH} 8.0(\boldsymbol{\nabla})$ and $\mathrm{pH} 9.0(\bullet))$, and glycine/ $\mathrm{NaOH}$ buffer $(\mathrm{pH}$ $10.0(\mathbf{4}))$.

of the enzyme for glycerol was calculated to be $2 \mathrm{mM}$ and $V_{\max }$ to be $1.15 \mathrm{U} / \mathrm{mL}$, being values similar to the literature [16].

\subsection{Response surface experiments}

The significant effects of temperature $(T)$, initial substrate concentration $(S), \mathrm{pH}$ value and interactions $(T \times \mathrm{pH}$ and $S \times \mathrm{pH}$ ) on glycerol kinase activity are shown in Table 2 . Temperature showed to have significant effects, both at linear and quadratic levels, on enzyme activity. The negative quadratic effect indicates that the effect of temperature on glycerol kinase activity may be described by a convex surface. Also, the increase in substrate concentration and in $\mathrm{pH}$ of the reaction medium will be accompanied by a linear increase in enzyme activity (positive linear effects). No significant effects of $S$ or $\mathrm{pH}$ at quadratic levels were observed.

Table 2

Effect estimates of the factors temperature $(T)$, substrate concentration $(S)$ and $\mathrm{pH}$, at linear ( $\mathrm{L}$ ) and quadratic $(\mathrm{Q})$ levels, and of the respective interactions on the activity of glycerol kinase (only significant effects of $p \leq 0.5$ or those having a confidence range smaller than the value of the effect, or smaller than the standard deviation (data not shown), were considered)

\begin{tabular}{lrl}
\hline Factor/interaction & Effect & $p$ value \\
\hline Temperature (L) & -0.1734 & 0.0000 \\
Temperature (Q) & -0.7773 & 0.0000 \\
Substrate (L) & 0.0646 & 0.0006 \\
$\mathrm{pH}(\mathrm{L})$ & 0.4386 & 0.0000 \\
$T \times \mathrm{pH}$ & -0.2516 & 0.0000 \\
$S \times \mathrm{pH}$ & 0.0279 & 0.0802 \\
\hline
\end{tabular}

A significant negative interaction between $T$ and $\mathrm{pH}(T \times \mathrm{pH})$ and a positive significant interaction between $S$ and $\mathrm{pH}(S \times \mathrm{pH})$ were observed. Thus, a simultaneous increase in $T$ and $\mathrm{pH}$ will conduct to a decrease in enzyme activity. Conversely, a simultaneous increase in $S$ and $\mathrm{pH}$ will be accompanied by an increase in enzyme activity. However, no significant interaction between $T$ and $S(T \times S)$ was detected.

The experimental data points can be described by the following second-order polynomial model:

$$
\begin{aligned}
\text { Activity }= & -23.6088+0.6665 T-0.0048 T^{2}-0.0020 S \\
& +1.0754 \mathrm{pH}-0.0156(T \times \mathrm{pH})+0.0003(S \times \mathrm{pH})
\end{aligned}
$$

where the activity is expressed in $\mathrm{U} / \mathrm{mol}, T$ is the temperature $\left({ }^{\circ} \mathrm{C}\right)$ and $S$ is the substrate concentration $(\mathrm{mM})$. In this model equation, only the factors and the interactions showing significant effects of $p \leq 0.5$, or having a confidence range smaller than the value of the effect, or smaller than the standard deviation (data not shown), were considered. In fact, these later effects have a lower probability, but their values are not small enough to be neglected [48].

This model has high values of both $R^{2}(0.9928)$ and $R_{\text {adj }}^{2}$ (0.9899), indicating that it explains more than $99 \%$ of the variability of the experimental data. Therefore, a close agreement between the experimental results and the theoretical values predicted by this model is attained $[48,51]$. This can be illustrated by Fig. 6, showing a close correlation between predicted values versus observed values. Also, this model fitted to the experimental points of enzyme activity is represented by a saddle-like surface. Since 3 variables (factors) were considered, the response is in a 4 th axe. Thus, the 4-dimensional saddle-like response surface is represented by two 3-dimensional surfaces, as a function of 2 of the 3 variables, keeping the 3 rd variable constant and equal to its centre point value (Fig. 7). Saddle-like surfaces do not have a defined stationary point (maximum) but they are characterized by having infinity of data points that maximize the response. Thus, in this case, the analysis of contour plots is useful to find out the best regions in the experimental domain (Fig. 8). Higher

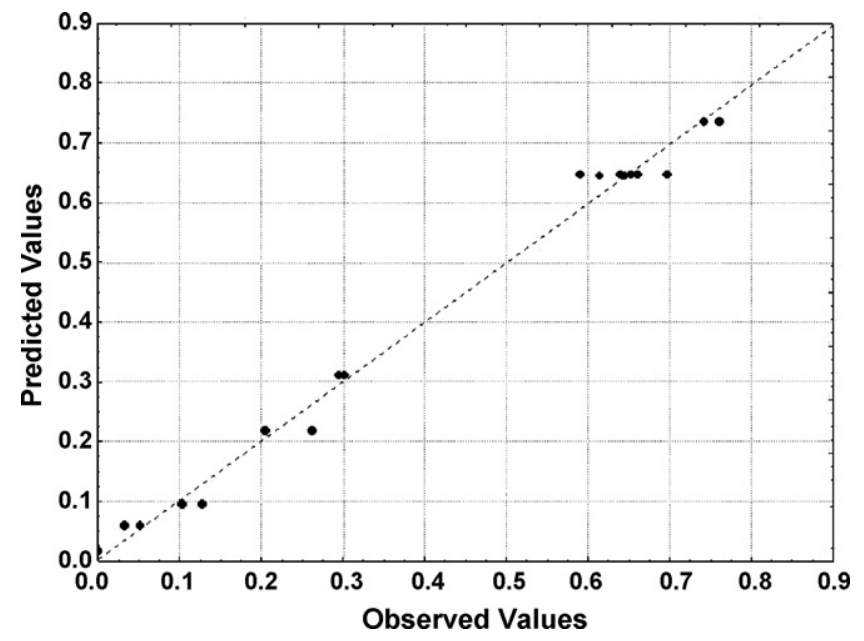

Fig. 6. Linear relationship between the experimental values and the corresponding values predicted by the second-order polynomial model. 

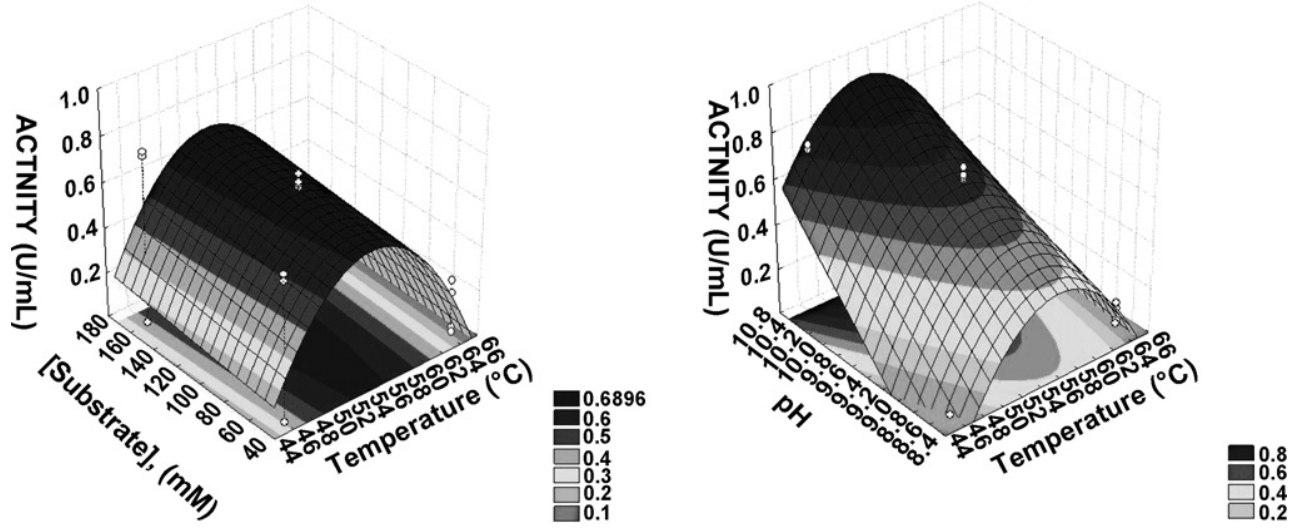

Fig. 7. Response surface fitted to the experimental data points corresponding to the activity of glycerol kinase, as a function of temperature and initial substrate concentration, at $\mathrm{pH}$ of 9.5 , and as a function of temperature and $\mathrm{pH}$, at initial substrate concentration of $105 \mathrm{mM}$.
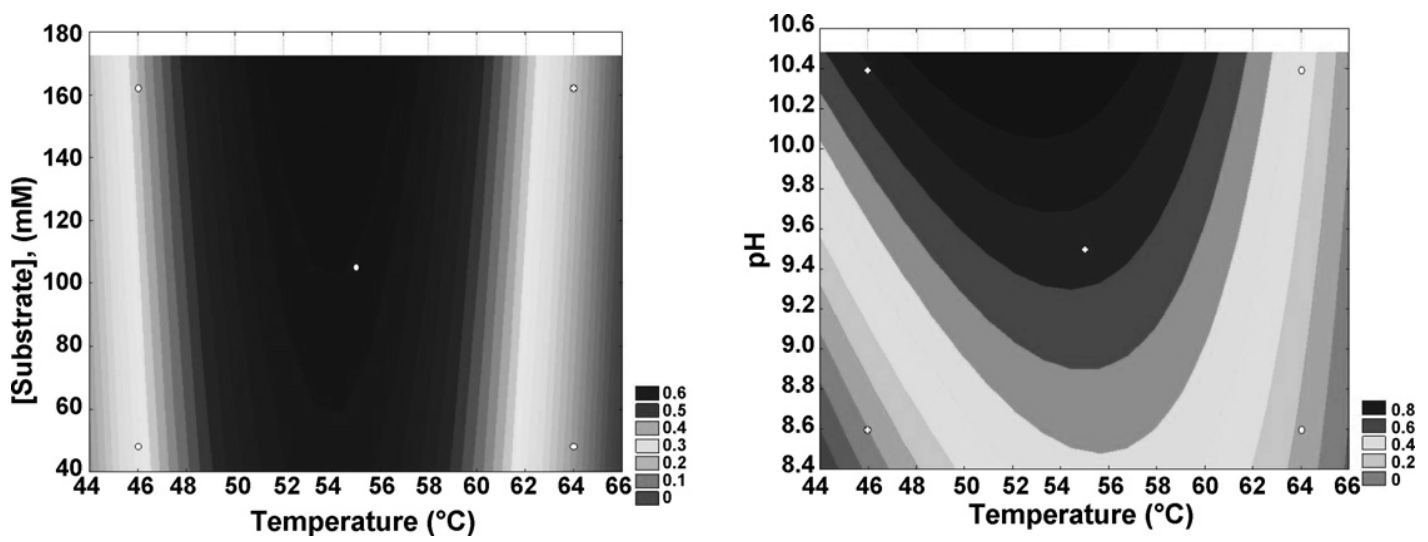

Fig. 8. Contour plots of the response surface presented in Fig. 7.

activity values will be attained at temperatures between 52 and $56^{\circ} \mathrm{C}, \mathrm{pH}$ around $10.2-10.5$ and substrate concentrations from 150 to $170 \mathrm{mM}$.

The response surface and respective contour plot show that the effect of temperature in GK activity is more pronounced than that of $\mathrm{pH}$ and much more than that of substrate concentration, inside the experimental range tested. An increase in temperature up to values around $50^{\circ} \mathrm{C}$ is accompanied by an increase in enzyme activity; for temperatures higher than $55-60^{\circ} \mathrm{C}$, a thermal inactivation is observed. The interaction between $\mathrm{pH}$ and temperature is well observed both in response surfaces and in contour plots, showing that it cannot be ignored. The effect of substrate concentration is not very pronounced because the values tested were rather high. However, the $T$ and $\mathrm{pH}$ ranges suggested by RSM are not very far from the apparent optima suggested by the preliminary experiments $\left(T=60^{\circ} \mathrm{C} ; \mathrm{pH} 10\right)$. The differences may be explained by the existence of significant interactions $(T \times \mathrm{pH})$ and $(S \times \mathrm{pH})$ that were ignored in the classical approach followed in the preliminary experiments.

\section{Conclusion}

The results obtained showed that the colorimetric method using enzymatic preparations, obtained from dry baker's yeast, turned into a simple methodology with low cost-effectiveness, with wide application, and will be used in the glycerol deter- mination. This method compared with a commercial kit for this purpose, and containing purified enzymes $\left(\right.$ Sigma $\left.^{\circledR}\right)$, presented a reduction of costs of approximately $88.4 \%$. RSM showed to be an adequate approach for modeling the reaction and optimization of reaction conditions to maximize glycerol kinase activity.

\section{Acknowledgements}

The authors are grateful for the financial support provided by FAPESP and PADC/FCF/UNESP.

\section{References}

[1] P. Fossati, L. Prencípe, Clin. Chem. 28 (1982) 2077-2080.

[2] H.U. Bergmeyer, G. Holz, E.M. Kauder, H. Mollering, O. Wieland, Biochem. Z. 333 (1961) 471-480.

[3] S. Hayashi, E.C.C. Lin, J. Biol. Chem. 242 (1967) 1030-1035.

[4] M.J. Comer, C.J. Bruton, T. Atkinson, J. Appl. Biochem. 1 (1979) 259270.

[5] V. Charrier, E. Buckley, D. Parsonage, A. Galinier, E. Darbon, M. Jaquinod, E. Forest, J. Deutscher, A. Claiborne, J. Biol. Chem. 272 (1997) 14166-14174.

[6] H.P. Schweizer, R. Jump, C. Po, Microbiology 143 (1997) 1287-1297.

[7] S.E. Pasteris, A.M. Strasser de Saad, Lett. Appl. Microbiol. 27 (1998) 93-97.

[8] O. Wieland, M. Suyter, Biochem. Z. 329 (1957) 320-331.

[9] D.W. Pettigrew, D.P. Ma, C.A. Conrad, J.R. Johnson, J. Biol. Chem. 263 (1988) 135-139. 
[10] C. Holmberg, L. Beijer, B. Rutberg, L. Rutberg, J. Gen. Microbiol. 136 (1990) 2367-2375.

[11] P. Pavlik, M. Simon, T. Schuster, H. Ruis, Curr. Genet. 24 (1993) 21-25.

[12] H. Huang, T. Kabashima, K. Ito, C. Yin, Y. Nishiya, Y. Kawamura, T. Yoshimoto, Biochim. Biophys. Acta 1382 (1998) 186-190.

[13] S. Sakasegawa, I. Yoshioka, S. Koga, M. Takahashi, K. Matsumoto, H. Misaki, T. Ohshima, Biosci. Biotechnol. Biochem. 62 (1998) 23882395.

[14] C.A. Sargent, C. Young, S. Marsh, M.A. Ferguson-Smith, N.A. Affara, Hum. Mol. Genet. 3 (1994) 1317-1324.

[15] D.C. Crans, G.M. Whitesides, J. Am. Chem. Soc. 107 (1985) 7008-7018.

[16] A. Nilsson, K.S. Thomson, L. Adler, Biochim. Biophys. Acta 991 (1989) 296-302.

[17] H. Huang, T. Yoshida, Y. Meng, T. Kabashima, K. Ito, Y. Nishiya, Y. Kawamura, T. Yoshimoto, J. Ferment. Bioeng. 83 (1997) 328-332.

[18] J. Deutscher, H. Sauerwald, J. Bacteriol. 166 (1986) 829-836.

[19] G.F. Sprague, J.E. Cronan, J. Bacteriol. 129 (1977) 1335-1342.

[20] H.S. Huang, T. Yoshida, Y. Meng, T. Kabashima, K. Ito, Y. Nishiya, Y. Kawamura, T. Yoshimoto, J. Ferment. Bioeng. 83 (1997) 328-332.

[21] N. Westergaard, P. Madsen, K. Lundgren, Biochim. Biophys. Acta 1402 (1998) 261-268.

[22] I. Králová, D.J. Rigden, F.R. Opperdoes, P.A.M. Michels, Eur. J. Biochem. 267 (2000) 2323-2333.

[23] J. Hettwer, H. Oldenburg, E. Flaschel, J. Mol. Catal. B: Enzym. 19-20 (2002) 215-222.

[24] S.E. Pasteris, A.M. Strasser de Saad, Food Microbiol. 22 (2005) 399407.

[25] J.W. Thorner, H. Paulus, J. Biol. Chem. 248 (1973) 3922-3932.

[26] M.J. North, J. Bacteriol. 120 (1974) 741-747.

[27] R.T. Voegele, G.D. Sweet, W. Boos, J. Bacteriol. 175 (1993) 1087-1094.

[28] J. Le Petit-Thevenin, O. Nobili, A.V. Crine, C. Jacquier, J. Boyer, Nutr. Biochem. 8 (1997) 312-315.

[29] N. Kuwada, K. Nagano, N. MacLennan, J. Havens, M. Kumar, K.M. Dipple, E.R.B. McCabe, Biochem. Biophys. Res. Commun. 335 (2005) 247255.

[30] D.M. Hercules, T.L. Sheehan, Anal. Chem. 50 (1978) 521-525.

[31] M.C. Gacula Jr., J. Singh, Statistical Methods in Food and Consumer Research. Food Science and Technology. A Series of Monographs, Academic Press, Orlando, 1984, pp. 214-272.
[32] D.C. Montgomery, Design and Analysis of Experiments, John Wiley and Sons, New York, 1991, 649 pp.

[33] R.L. Strobel, W. Nakatsukasa, J. Ind. Microbiol. 11 (1993) 121-127.

[34] R. Sen, J. Chem. Technol. Biotechnol. 68 (1997) 263-270.

[35] G.K. Robinson, M.J. Alston, C.J. Knowles, P.S.J. Cheetham, K.R. Motion, Enzyme Microb. Technol. 16 (1994) 855-863.

[36] M.H.L. Ribeiro, D. Silveira, C. Ebert, S. Ferreira-Dias, J. Mol. Catal. B Enzym. 21 (2003) 81-88.

[37] C.-J. Shieh, C.C. Akoh, P. Koehler, J. Am. Oil Chem. Soc. 72 (1995) 619-623.

[38] X. Xu, A.R.H. Skands, C.-E. Høy, H. Mu, S. Balchen, J. Adler-Nissen, J. Am. Oil Chem. Soc. 75 (1998) 1179-1186.

[39] N.M. Osório, S. Ferreira-Dias, J.H. Gusmão, M.M.R. da Fonseca, J. Mol Catal. B: Enzym. 11 (2001) 677-686.

[40] S. Ferreira-Dias, A.C. Correia, F.O. Baptista, M.M.R. da Fonseca, J. Mol. Catal. B: Enzym. 11 (2001) 699-711.

[41] A.C. Nascimento, C.S.R. Tecelão, J.H. Gusmão, M.M.R. da Fonseca, S. Ferreira-Dias, Eur. J. Lipid Sci. Technol. 106 (2004) 599-612.

[42] P. Pires-Cabral, M.M.R. da Fonseca, S. Ferreira-Dias, Biochem. Eng. J. 33 (2007) 148-158.

[43] S. Ferreira-Dias, M.H.L. Ribeiro, P.A.S. Lourenço, Bioprocess Eng. 22 (2000) 407-412.

[44] J.P. Silva, S. Sousa, I.C. Gonçalves, J.J. Porter, S. Ferreira-Dias, Sep. Purif Technol. 40 (2004) 163-170.

[45] C.-X. Cai, K.-H. Xue, Y.-M. Zhou, H. Yang, Talanta 44 (1996) 339-343.

[46] M. Šůcková, K.B. Demnerová, K. Bond, B. Králová, Enzyme Microb. Technol. 4 (1992) 917-922.

[47] E. Layne, in: S.P. Colowick, N.O. Kaplan (Eds.), Spectrophotometric and Turbidimetric Methods, Elsevier, Academic Press, New York, 1957, pp. 447-450.

[48] P.D. Haaland, in: D.B. Owen (Ed.), Experimental Design in Biotechnology, Statistics: Textbooks and Monographs, Marcel Dekker Inc., New York, 1989, $258 \mathrm{p}$.

[49] P.E. Kennedy, in: S.P. Colowick, N.O. Kaplan (Eds.), Glycerokinase, Academic Press, New York, 1962, pp. 476-479.

[50] Y. Koga, M. Haruki, M. Morikawa, S. Kanaya, J. Biosci. Bioeng. 91 (2001) $551-556$.

[51] S. Weisberg, Applied Linear Regression, John Wiley \& Sons, New York, $1985,217 \mathrm{pp}$ 